\title{
Homoeopathic thyroidinum $3 x$-an adjuvant in the treatment of hypothyroidism
}

\begin{abstract}
A clinical study was conducted to assess the role of homoeopathic remedy Thyroidinum $3 \mathrm{X}$ in the treatment of Hypothyroidism. Thyroidinum $3 \mathrm{X}$ was introduced as an adjuvant (supportive therapy) along with synthetic Levothyroxine.
\end{abstract}

Background and Objectives: Lack of thyroxine hormones in reproductive age group affects the health of progeny and healthy future of entire society. There is no cure available for Hypothyroidism but it is controllable. Synthetic Levothyroxine remains as a conventional and lifelong therapy for Hypothyroidism. This study is aimed at arriving to a viable homoeopathic solution by using the remedy Thyroidinum $3 \mathrm{X}$ which is considered as a specific supplement for Hypothyroidism. A randomized Placebo controlled study was conducted with 30 known cases of Primary Hypothyroidism. By simple random sampling the samples were allotted in to study group and control group. Synthetic Levothyroxine remained as the mainstream therapy in both the groups. All 30 cases were taking Levothyroxine $100 \mathrm{mcg}$ during enrollment. Depend upon the changes in TSH levels their dosage were modified by an Endocrinologist. Thyroid function test (T3, T4, TSH) was done before, during and after the intervention.

Results: The combined therapy of homoeopathic remedy Thyroidinum $3 \mathrm{X}$ and Levothyroxine has beneficial effects. Remarkable weight loss and symptomatic relief was obtained with Thyroidinum $3 \mathrm{X}$.

Conclusion: From the above results and observations it is concluded that Thyroidinum $3 \mathrm{X}$ hastens the curative process in primary Hypothyroidism. No adverse effects were recorded when homoeopathic remedy Thyroidinum $3 \mathrm{X}$ was given along with allopathic Levothyroxine. It is concluded from the percentage of symptomatic relief $(50 \%$ to $90 \%)$ that Thyroidinum $3 \mathrm{X}$ is much useful in treating the symptoms of Hypothyroidism.

Keywords: hypothyroidism, homoeopathy, thyroidinum 3x, levothyroxine, adjuvant therapy
Volume II Issue I - 2018

\section{Kiruthiga $S$}

Department of Homoeopathic Materia Medica, Bharati

Vidyapeeth Homoeopathic Medical College, India

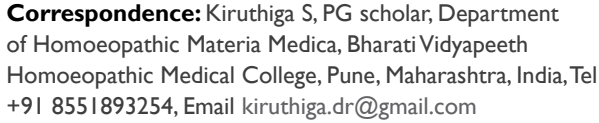

+918551893254, Email kiruthiga.dr@gmail.com

Received: November 01, 2017 | Published: January 16, 2018
Abbreviation: TSH, thyroid stimulating hormone; PCOD, polycystic ovarian disease; mcg, microgram

\section{Introduction}

Hypothyroidism is a hypometabolic state resulting from inadequate secretion of thyroid hormones for a longer period or rarely from resistance of the peripheral tissues to the effects of thyroid Hormones. ${ }^{1}$ The prevalence of Hypothyroidism has increased to 5:100 with high female preponderance. It accounts as a major risk factor in pregnancy and infertility. The prevalence of gestational Hypothyroidism is estimated as $13.13 \%$ in India. ${ }^{2}$ Untreated, maltreated gestational Hypothyroidism results in impaired intellectual, cognitive and neural functions of newborn. Attention deficit and hyperactive syndromes are common in children who were born to hypothyroid mother. ${ }^{3}$

Thyroid hormones have influence over oestrogen and androgen metabolism. This is evident by the history of delayed puberty, menstrual irregularities, anovulatory cycles, miscarriage and infertility in hypothyroid individuals. ${ }^{4,5}$ Hypothyroidism accounts a major risk factor in $53.7 \%$ cases of Infertility. ${ }^{6}$

In 1981 Dr. George Murray (who was a pioneer in the treatment of Endocrine disorder) used the extraction of sheep"s thyroid gland as hypodermal injections for the treatment of Myxoedema. This method was called as "Thyroid feeding"? Various alarming signs such as sudden cardiac failure, loss of conscious and tonic spasm were developed along with marked improvement in myxoedema. Due to these fatal effects injections were converted into oral dose and remained as a conventional therapy until the introduction of synthetic Levothyroxine in $1927 .{ }^{8}$

\section{Thyroidinum $3 \mathrm{X}$}

The homoeopathic remedy Thyroidinum $3 \mathrm{X}$ is a potentised form of sheep"s thyroid gland and it was proved using a double blind method. On knowing the pathogenic effects of crude thyroid feeding the British Homoeopath Dr.J.H.Clarke repeated the proving of sheep"s thyroid gland as an attenuated homoeopathic remedy Thyroidinum. $\mathrm{He}$ has cured many cases of thyroid enlargement presented with amenorrhoea, sleeplessness, constipation, obesity and odema of the face. ${ }^{9} \mathrm{He}$ had witnessed a rise in bone density and restoration of hair growth in cases of Myxoedema after administering Thyroidinum 3X.

Indian Homoeopath Dr.S.K.Ghosh has elaborated the use of Thyroidinum in various diseases that are arising from metabolic, nervous or vascular imbalances. He has also recorded the benefits of Thyroidinum in various potencies other than $3 \mathrm{X}$ potency. ${ }^{9}$ 


\section{Comparison of levothyroxine and thyroidinum}

A preliminary scientific study was conducted to compare the quality of Levothyroxine with Thyroidinum $3 \mathrm{X}$ by using UV spectroscopy. Synthetic Levothyroxine 50mcg tablet was compared with Thyroidinum 3X tablet of Wilmer Schwabe company (which is used in this study also). Even though they are derived from dissimilar sources their peaks (quality) are similar under UV spectroscopy. ${ }^{10}$ The study concludes that the action and quality of Levothyroxine is comparable with homoeopathic remedy Thyroidinum 3X.

The system of Homoeopathy is based on the theory of individualization and symptom similarity of the patient with the drug. Though it treats every sickness of man as an individual entity there are numerous examples of clinical and therapeutic trials emerging in the field of Homoeopathy. This study will help to know the action of Thyroidinum $3 \mathrm{X}$ in both biochemical and symptomatic level.

\section{Null hypothesis}

Thyroidinum $3 \mathrm{X}$ does not have any role in altering the TSH levels.

\section{Materials and methods}

\section{Study setup}

Study is conducted at Bharati Vidyapeeth Homoeopathic Hospital, Pune, India.

\section{Subjects}

30 Cases of Primary Hypothyroidism with Levothyroxine $100 \mathrm{mcg}$ as mainstream therapy.

\section{Inclusion Criteria}
a. 20 to $40 \mathrm{yrs}$ of age and both sex
b. Primary Hypothyroidism with unknown cause.
c. Diagnosed in last 5years
d. TSH levels are less than $10 \mathrm{IU} / \mathrm{ml}$.
e. Under Levothyroxine $100 \mathrm{mcg}$ intake.

\section{Exclusion criteria}
a. Autoimmune Hypothyroidism
b. Hypothyroidism associating with PCOD, Diabetes mellitus and Hypertension.
c. Hypothyroidism in pregnancy.
d. Menopause.

\section{Duration}

6 to 9 months.

\section{Study parameter}

Serum TSH levels.

\section{Study procedure}

30 diagnosed cases of Primary Hypothyroidism were enrolled with Levothyroxine $100 \mathrm{mcg}$ as mainstream therapy. For all the 30 cases T3, T4, TSH levels were checked prior enrollment. The homoeopathic remedy Thyroidinum $3 \mathrm{X}$ was given twice daily along with Levothyroxine in 15 cases. In another 15 cases Placebo was given twice daily along with Levothyroxine. Thyroidinum $3 \mathrm{X}$ and Placebo was identical in size and appearance (single blinding). Monthly follow ups were taken for all 30 cases. The dose of Levothyroxine was monitored by a reputed Endocrinologist. T3, T4, TSH levels were checked every 3 months for the Placebo receiving group. Symptomatic and biochemical changes were recorded during the entire period of study. In all 15 cases of study group thyroid function tests (T3, T4, $\mathrm{TSH}$ ) was done one month after the intervention of Thyroidinum $3 \mathrm{X}$ and consequently based on the levels of TSH.

\section{Statistical analysis}

Statistical analysis paired $\mathrm{t}$ - test was done by using the TSH levels taken before, during and after the study.

\section{Results and discussion}

30 cases were enrolled from Pune, Maharashtra for the study. Inspite of normal TSH levels the cases were presenting with various symptoms such as weight gain $40 \%(n=12)$, Hairfall $20 \%(n=6)$, weakness and lethargy $17 \%(\mathrm{n}=5)$, sleep disturbances $10 \%(\mathrm{n}=3)$, memory weakness $7 \%(\mathrm{n}=2)$, hoarseness of voice and dry skin. Thyroidinum $3 \mathrm{X}$ and Placebo were given twice daily for the entire period of study along with mainstream Levothyroxine therapy.

\section{Demographic distribution}

Though all the cases were enrolled from pune, they were belonging to various parts of India.

\begin{tabular}{ll}
\hline Area & No. of. cases \\
\hline Maharashtra & 19 \\
Tamilnadu & 4 \\
Punjab & 3 \\
Rajasthan & 2 \\
Calcutta & 2 \\
\hline
\end{tabular}

\section{Age distribution between the groups}

Mean age and Male, Female ratio of both the groups were slightly differed from each other. Female preponderance is noticed.

\begin{tabular}{lll}
\hline Age & $\begin{array}{l}\text { Thyroidinum 3X } \\
\text { (Study Group) }\end{array}$ & $\begin{array}{l}\text { Placebo (Control } \\
\text { Group) }\end{array}$ \\
\hline Mean age & 35.53 & 34 \\
21 to $25 y r s$ & $\mathrm{I}$ & $\mathrm{I}$ \\
26 to $30 y r s$ & $\mathrm{I}$ & $\mathrm{I}$ \\
3 I to $35 y r s$ & 4 & 7 \\
36 to 39 yrs & 5 & 2 \\
40 yrs & 5 & 4 \\
Male, Female ratio & $4: 11$ & $3: 12$ \\
\hline
\end{tabular}

\section{TSH levels during enrollment}

The upper and lower limits of TSH levels were fixed before enrollment. Cases fulfilling these criteria were enrolled for the study. Normal TSH level is -0.4 to $4.0 \mathrm{micro}$ IU $/ \mathrm{ml}$. 
Lower limit of TSH -0.5 micro IU $/ \mathrm{ml}$

Higher limit of TSH - 10microIU/ml

\begin{tabular}{lll}
\hline TSH levels & $\begin{array}{l}\text { Thyroidinum } 3 \times \text { (Study } \\
\text { Group) }\end{array}$ & $\begin{array}{l}\text { Placebo (Control } \\
\text { Group) }\end{array}$ \\
\hline 0 to 2 & 3 & 3 \\
2 to 4 & 1 & 3 \\
4 to 6 & 1 & 3 \\
6 to 8 & 7 & 4 \\
8 to 10 & 3 & 2 \\
\hline
\end{tabular}

\section{The outcome of the study}

As stated earlier, cases were experiencing the symptoms of Hypothyroidism even with normal TSH levels and proper dosage of Levothyroxine. Symptomatic relief, weight loss and changes in TSH levels were considered as an assessment tool. Along with this parameter, changes in Levothyroxine doses were also considered as an outcome. The Levothyroxine dose is mainly based on the TSH levels and symptom severity of the patient. Thus a reduction in Levothyroxine dose indicates improved functions of Thyroid gland. There were steady and remarkable weight loss achieved in study group with the help of Thyroidinum $3 \mathrm{X}$.

\begin{tabular}{|c|c|c|}
\hline Parameter & $\begin{array}{l}\text { Thyroidinum } 3 X \\
\text { (Study group) }\end{array}$ & $\begin{array}{l}\text { Placebo (Control } \\
\text { group) }\end{array}$ \\
\hline $\begin{array}{l}\text { Symptomatic } \\
\text { relief }\end{array}$ & $50 \%$ to $90 \%$ & $30 \%$ to $60 \%$ \\
\hline Weight loss & I kg to $4.5 \mathrm{kgs}$. & 0 to $1 \mathrm{~kg}$ \\
\hline $\begin{array}{l}\text { Reduction in } \\
\text { serum TSH levels }\end{array}$ & $100 \%(n=15)$ & $\begin{array}{l}20 \%(n=3) \\
27 \%(n=4) \text { after increasing } \\
\text { Levothyroxine dosage. }\end{array}$ \\
\hline $\begin{array}{l}\text { Levothyroxine } \\
\text { less than } 100 \mathrm{mcg} \text {. }\end{array}$ & $73 \%(n=11)$ & $27 \%(n=4)$ \\
\hline $\begin{array}{l}\text { Levothyroxine } \\
\text { more than } \\
\text { I00mcg }\end{array}$ & Nil & $40 \%(n=6)$ \\
\hline
\end{tabular}

\section{Statistical analysis}

Paired t-test was done by using the TSH levels taken before, during and after the study.

\begin{tabular}{lll}
\hline & Placebo group & Thyroidinum group \\
\hline Mean & $\mathrm{XI}=5.20$ & $\mathrm{X} 2=4.30$ \\
$\mathrm{SD}$ & $\mathrm{SI}=4.73$ & $\mathrm{~S} 2=3.1 \mathrm{I}$ \\
P value & 0.05 & 0.05 \\
\hline
\end{tabular}

$\mathrm{t}$ calculation (4.74) $>\mathrm{t}$ value (1.96). Null hypothesis is rejected.

Conclusion: Thyroidinum $3 \mathrm{X}$ is capable of altering TSH levels.

Pie chart depicting various doses of Levothyroxine at the end of study.

a. In Thyroidinum group: No further increase of Levothyroxine dose. Almost $73 \%(n=11)$ of cases underwent a reduction in
Levothyroxine dosage. Remaining $27 \%(n=4)$ of cases are gradually improving symptomatically and their TSH levels are decreasing gradually. A minimum of $1 \mathrm{~kg}$ to $4.5 \mathrm{kgs}$ weight loss achieved with Thyroidinum $3 \mathrm{X}$. The Levothyroxine doses have been reduced from $100 \mathrm{mcg}$ to $25 \mathrm{mcg}$. There were no further rise in Levothyroxine dosage in the combined treatment with Thyroidinum $3 \mathrm{X}$. It indicates that the regulation of thyroid hormones are accelerated with Thyroidinum $3 \mathrm{X}$.

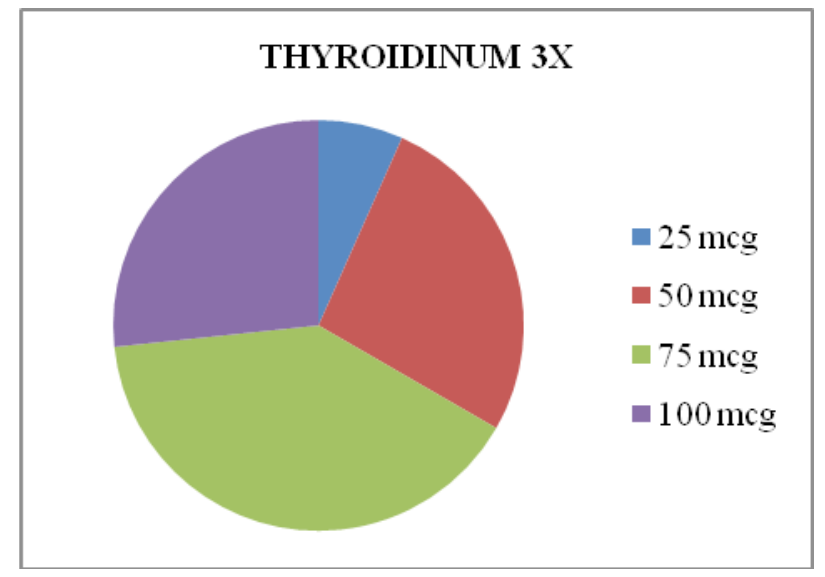

b. In placebo group

Only those cases which are enrolled with TSH levels below 2 micro IU/ml underwent a reduction in Levothyroxine doses. Others remained with same or higher dosage. No remarkable weight loss achieved in a period of 6 months.

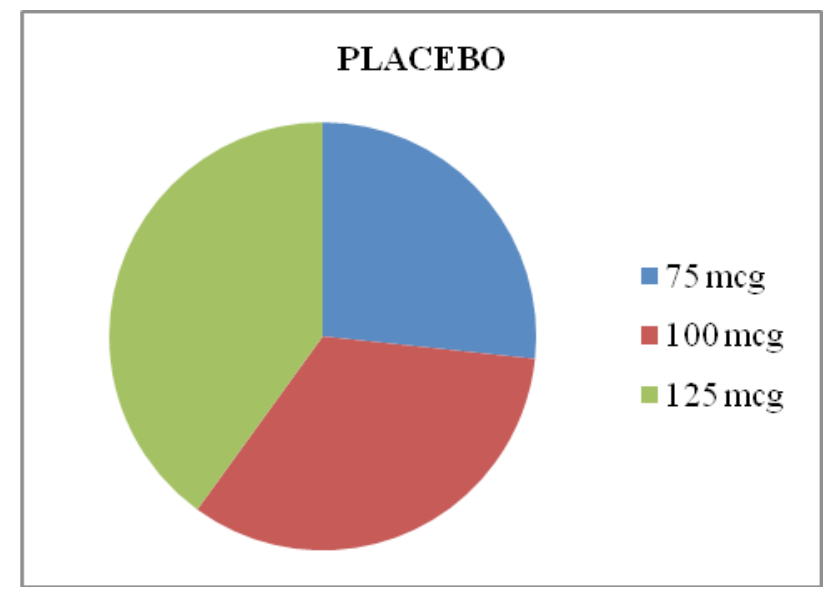

Obesity has significant impact over the serum TSH levels. Obese individuals tend to have higher TSH levels even with proper dosage of Levothyroxine. Similarly weight loss gives immense benefit to a hypothyroid individual in reducing symptoms as well as medications. No adverse effects were recorded during the combined therapy of homoeopathic remedy Thyroidinum $3 \mathrm{X}$ and Levothyroxine. Reduction of Levothyroxine dosage and reduced TSH levels indicate the improved functions of thyroid gland. Lower the doses higher the chances of cure.

\section{Conclusion}

From the above results and observations it is concluded that Thyroidinum $3 \mathrm{X}$ hastens the curative process in primary Hypothyroidism. No adverse effects were recorded when 
homoeopathic remedy Thyroidinum $3 \mathrm{X}$ was given along with allopathic Levothyroxine. It is concluded from the percentage of symptomatic relief $(50 \%$ to $90 \%)$ that Thyroidinum $3 \mathrm{X}$ is much useful in treating the symptoms of Hypothyroidism.

\section{Acknowledgements}

Prof. Dr.G.K.Oberoi, HOD, Department of Homoeopathic Materia Medica, BVDU Homoeopathic Medical College, Pune, India.

\section{Conflict of interest}

The authors declare they have no conflict of interest.

\section{References}

1. Harrison"s. Principles of Internal Medicine. 16th ed. USA: McGrawHill companies, Inc; 2004.

2. Sahay RK, Nagesh VS. Hypothyroidism in Pregnancy. Indian J Endocr Metab. 2012;16(3):364-370.

3. Ghassabian A, Bongers-Schokking JJ, de Rijke YB, et al. Maternal thyroid autoimmunity during pregnancy and the risk of attention deficit/ hyperactivity problems in children; The generation R study. Thyroid. 2012;22(2):178-186.
4. Unisa S. Childishness in Andrapradesh. Reprod Health Matters. 1999;7:54-64.

5. Zargar AH, Wani AI, Masoodi SR, et al. Epidemiologic and etiologic aspects of primary infertility in the Kashmir region of India. Fertil Steril. 1997;68(4):637-643.

6. Priya DM, Akhtar N, Ahmad J. Prevalence of hypothyroidism in Infertile women and evaluation of response of treatment for hypothyroidism on Infertility. Indian J Endocr Metab. 2015;19:504-506.

7. Slater S. The discovery of thyroid replacement therapy. Part 3:A complete transformation. J R Soc Med. 2011;104(3):100-106.

8. Clarke JH. A Dictionary of Practical Materia Medica. 2nd ed. London: Homeopathic Publishing company; 1902. p. 1437-1442.

9. Ghosh SK. Clinical experience with some rare Nosodes. India: Jain Publishers; 1998. p. 3-4.

10. Valavan, Dhyani P. Thyroidinum $3 X$ in comparison with Thyroxine- $A$ preliminary scientific study results. India: Homeo For all; 2012. p. 27-30. 